\title{
TRPV1 Expression Defines Functionally Distinct Pelvic Colon Afferents
}

\author{
Sacha A. Malin, ${ }^{1,3}$ Julie A. Christianson, ${ }^{1,3}$ Klaus Bielefeldt, ${ }^{1,3}$ and Brian M. Davis ${ }^{1,2,3}$ \\ ${ }^{1}$ Department of Medicine, Division of Gastroenterology, Hepatology, and Nutrition, ${ }^{2}$ Department of Neurobiology, and ${ }^{3}$ Pittsburgh Center for Pain \\ Research, University of Pittsburgh School of Medicine, Pittsburgh, Pennsylvania 15213
}

\begin{abstract}
Changes in primary sensory neurons are likely to contribute to the emergence of chronic visceral pain. An important step in understanding visceral pain is the development of comprehensive phenotypes that combines functional and anatomical properties for these neurons. We developed a novel ex vivo physiology preparation in mice that allows intracellular recording from colon sensory neurons during colon distension, in the presence and absence of pharmacologic agents. This preparation also allows recovery of functionally characterized afferents for histochemical analysis. Recordings obtained from L6 dorsal root ganglion cells in C57BL/6 mice identified two distinct populations of distension-responsive colon afferents: high-firing frequency (HF) and low-firing frequency (LF) cells. Fluid distension of the colon elicited rapid firing $(>20 \mathrm{~Hz})$ in $\mathrm{HF}$ cells, whereas LF cells seldom fired $>5 \mathrm{~Hz}$. Distension response thresholds were significantly lower in $\mathrm{HF}$ cells ( $\mathrm{LF}, 17.5 \pm 1.1 \mathrm{cmH}_{2} \mathrm{O} ; \mathrm{HF}, 2.6 \pm 1.0 \mathrm{cmH}_{2} \mathrm{O}$ ). Responses of most $\mathrm{LF}$ afferents to colon distension were sensitized

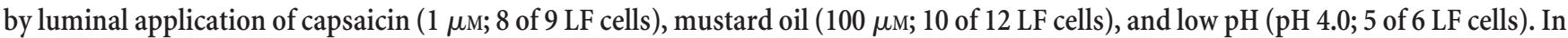
contrast, few HF afferents were sensitized by capsaicin ( 3 of 9), mustard oil ( 2 of 7 ), or low pH ( 1 of 6 ) application. Few HF afferents ( 4 of 23) expressed the capsaicin receptor, TRPV1. In contrast, 87\% (25 of 29) of LF afferents expressed TRPV1. TRPV1 has been shown to be required for development of inflammatory hyperalgesia. These results suggest a unique functional role of TRPV1-positive colon afferents that could be exploited to design specific therapies for visceral hypersensitivity.
\end{abstract}

Key words: visceral pain; TRPA1; capsaicin; mustard oil; nociceptor; inflammation

\section{Introduction}

Acute abdominal discomfort and pain is often triggered by inflammation or other identifiable injury. However, most patients with chronic abdominal pain do not show clear structural or biochemical abnormality, leading to a diagnosis of irritable bowel syndrome, dyspepsia, or other functional disease. Changes in visceral sensation such as hypersensitivity and hypervigilance likely contribute to common functional disorders, and visceral sensory input is a potentially important treatment target. Spinal afferents innervating the proximal or distal gastrointestinal tract have been characterized by response to organ distension in vivo as lowthreshold and high-threshold afferents (Sengupta and Gebhart, 1994a; Ozaki and Gebhart, 2001). Sixty to $70 \%$ of spinal afferents are low threshold and respond to distension pressures $<10$ $\mathrm{mmHg}$. High threshold afferents, in contrast, respond to distension pressures $>30 \mathrm{mmHg}$; these higher pressures correspond with the onset of nocifensive responses, suggesting a role for high threshold afferents in nociception (Ness and Gebhart, 1988; Naliboff et al., 1997; Ozaki et al., 2002). Gastrointestinal afferents

Received Aug. 11, 2008; revised 0ct. 3, 2008; accepted Nov. 18, 2008.

This work was supported by National Institutes of Health Grants NS31826 and NS050758 (B.M.D.) and DK080182 (J.A.C.). We thank Chris Sullivan for outstanding technical support and Dr. H. R. Koerber for invaluable consultations regarding the development of the ex vivo preparation.

Correspondence should be addressed to Brian M. Davis, Department of Medicine, Division of Gastroenterology, Hepatology, and Nutrition, E1440 Basic Medical Science Tower, University of Pittsburgh School of Medicine, 200 Lothrop Street, Pittsburgh, PA 15261.

DOl:10.1523/JNEUROSCI.3791-08.2009

Copyright $\odot 2009$ Society for Neuroscience $\quad$ 0270-6474/09/290743-10\$15.00/0 have been characterized in vitro as mucosal, muscular, or serosal by distinct mechanical response profiles, although these designations have not yet been confirmed by sufficiently detailed anatomical studies (Lynn and Blackshaw, 1999; Brierley et al., 2004). Despite divergent responses to mechanical stimuli, the majority of visceral sensory afferents is polymodal and also responds to thermal and chemical stimuli.

Mechanical sensitivity of visceral afferents is altered in mice lacking functional transient receptor potential vanilloid receptor 1 (TRPV1) channels (Birder et al., 2002; Rong et al., 2004; Jones et al., 2005; Daly et al., 2007). These results predict a role for TRPV1, a nonselective cation channel responsive to noxious heat, low $\mathrm{pH}$, and vanilloid compounds such as capsaicin (CAP) and anandamide (Caterina et al., 1997, 2000; Tominaga et al., 1998; Akopian et al., 2008; Ruparel et al., 2008), in visceral sensation. TRPV1 channels may detect stretch directly, via mechanical deformation of sensory neuronal endings or adjacent tissues, or indirectly, via compounds such as ATP released from surrounding tissues during stretch (Cooke et al., 2004; Koizumi et al., 2004). Alternatively, TRPV1 may modulate the overall sensitivity of polymodal visceral nociceptors to multiple stimuli.

In the present study, we describe a novel ex vivo preparation for intracellular recording of intact visceral afferents. Functionally characterized neurons were classified immunohistochemically, after intracellular neurobiotin injection via the recording electrode. We demonstrate that mechanically sensitive mouse colon afferents segregate into two groups based on firing frequency 
and distension response threshold. High firing-frequency neurons (HF) fire on approximately four times faster than low firingfrequency afferents (LF), exhibit greater adaptation, and have significantly lower distension response thresholds $(p<0.001$; $\mathrm{HF}, 2 \pm 1 \mathrm{cmH}_{2} \mathrm{O}$; LF, $17 \pm 1 \mathrm{cmH}_{2} \mathrm{O}$ ). Surprisingly, the majority $(87 \%)$ of $\mathrm{HF}$ afferents were TRPV1-negative, whereas nearly all (87\%) LF afferents expressed TRPV1 and could be sensitized by capsaicin, mustard oil (MO), and/or acid. These data suggest that TRPV1 channel activity modulates a specific subset of visceral afferents.

\section{Materials and Methods}

Animals. All experiments were performed in male and female mice (34 males; 16 females), 3-6 weeks of age, housed in a $12 \mathrm{~h}$ light/dark cycle with ad libitum access to water and food at the certified animal care facility of the University of Pittsburgh. All mice were bred in our vivarium. Animal handling adhered to the Guide for the Care and Use of Laboratory Animals (National Research Council); all procedures were approved by the Institutional Animal Care and Use Committee of the University of Pittsburgh. Two strains of wild-type mice were used: 30 $\mathrm{C} 3 \mathrm{H} / \mathrm{C} 57 \mathrm{BL} / 6$ hybrids (maintained at the University of Pittsburgh) and 20 C57BL/6 (originally from The Jackson Laboratory but bred for several generations in our facility). There was no difference in the data collected between the two lines of mice, and therefore data were pooled from all experiments.

Ex vivo preparation. Mice were killed using an overdose of isoflurane, injected with heparin, and transcardially perfused with $30 \mathrm{ml}$ of carboxygenated, ice-cold $\left(\sim 9^{\circ} \mathrm{C}\right)$ artificial CSF (sucrose-ACSF). To prevent excitotoxicity, sodium chloride was replaced by an iso-osmolar concentration of sucrose (sucrose-ACSF) (in mM: 253.9 sucrose, $1.9 \mathrm{KCl}, 1.2$ $\mathrm{KH}_{2} \mathrm{PO}_{4}, 1.3 \mathrm{MgSO}_{4}, 2.4 \mathrm{CaCl}_{2}, 26.0 \mathrm{NaHCO}_{3}, 10.0$ D-glucose). A laminectomy was then performed to expose lumbar and sacral spinal cord and dorsal root ganglia. The lower one-half of the animal was then removed to a separate dissection chamber circulating cold sucrose-ACSF. All abdominal organs except the colon were then removed. The colon was detached from the small intestines $\sim 1 \mathrm{~cm}$ distal to the cecum. Polyethylene tubing (PE 50) attached to a $10 \mathrm{cc}$ syringe containing perfusion solution was inserted into the anus and pressure was applied to expel fecal pellets through the proximal end of the colon. The pubic bone was split at the pubic symphysis, and the colon was freed from ventral attachments. The central primary ramus of one of the L6 spinal nerves (typically the left) was dissected free of the surrounding tissue and traced into the pelvic nerve. The colon was dissected free of all dorsal and lateral attachments except for the pelvic nerve and connective tissue surrounding the nerve. The vertebral column was reduced to bone, connecting ligaments, and the spinal cord adjacent to the L3-S1 spinal ganglia. The entire preparation was then moved into the recording dish perfused with chilled $\left(\sim 9^{\circ} \mathrm{C}\right.$ ) and carboxygenated ACSF (in mM: $127 \mathrm{NaCl}, 1.9 \mathrm{KCl}, 1.2$ $\mathrm{KH}_{2} \mathrm{PO}_{4}, 1.3 \mathrm{MgSO}_{4}, 2.4 \mathrm{CaCl}_{2}, 26.0 \mathrm{NaHCO}_{3}, 10.0$ D-glucose). The temperature was slowly raised to $33^{\circ} \mathrm{C}$. The rectum was intubated with $\mathrm{PE}$ tubing connected to a gravity-driven perfusion system for distension to $10,20,30$, and $40 \mathrm{cmH}_{2} \mathrm{O}$ (see Fig. 1). PE tubing was also inserted into the proximal end of the colon for drainage. This tubing was connected to a pressure transducer to monitor intracolonic pressure during distension. The position of proximal and distal tubes was secured through silk ligatures. The ventral rami of the L6 spinal nerve was traced to its entry point into the pelvic nerve, where a suction electrode was placed for electrical stimulation $\sim 3 \mathrm{~mm}$ distal to L6 DRG. Typically, the time from beginning perfusion to initiating recordings was $\sim 2.5 \mathrm{~h}$.

Electrophysiologic recordings. A total of 50 mice was used for these studies $(30 \mathrm{C} 3 \mathrm{H} / \mathrm{C} 57 \mathrm{BL} / 6$ and $20 \mathrm{C} 57 \mathrm{BL} / 6)$. Both male (34) and female (16) mice were analyzed. There was no strain or sex effect, and therefore all data were pooled. Recordings were made from individual L6 neurons using sharp borosilcate glass electrodes $(R>100 \mathrm{M} \Omega)$ filled with $1.0 \mathrm{M}$ potassium acetate and 5\% Neurobiotin (Vector Laboratories). Intracellular penetrations were recognized by a sudden voltage change. Electrophysiological responses were acquired with an Axoclamp 2B amplifier, sampled at $25 \mathrm{kHz}$, digitized (CED Micro 1401; Cambridge Electronic
Design) and stored on a computer (Gateway) using Spike 2 software (Cambridge Electronic Design). Cells generating an action potential in response to electrical stimulation of the pelvic nerve were tested with brief colon distension ( $<30 \mathrm{cmH}_{2} 0$ for $5 \mathrm{~s}$ ) and probing with a glass rod. If responses were elicited by either stimulus, a stepwise colon distension series was performed to pressures of $10,20,30$, and $40 \mathrm{cmH}_{2} \mathrm{O}$ with oxygenated bath solution. Each distension pressure lasted $20 \mathrm{~s}$, followed by drainage of the colon and a $20 \mathrm{~s}$ rest period before the next distension. In initial experiments, the distension series was repeated two to three times to determine whether colon afferents exhibited sensitization or habituation in response to repeated colon distension. Neither was seen in any of the cells examined in this manner (data not shown). Once the distension series was completed, the colon was drained and probed with von Frey hairs to identify receptive fields. After the initial distension series and von Frey probing, the cell was filled intracellularly with Neurobiotin (current injection; $1 \mathrm{nA}, 60 \mathrm{~s}$ ) for subsequent immunohistochemical identification. An additional distension series was then performed to examine the effect of Neurobiotin labeling and current injection on cellular response properties (action potential properties including threshold, distension response threshold, stimulus response function). Cells were rarely seen in which labeling altered response properties; these cells were excluded from additional experiments.

The colon was then infused with one or more of the following solutions: ACSF, pH 4, 5\% DMSO (vehicle), $1 \mu \mathrm{M}$ capsaicin in 5\% DMSO, or $100 \mu \mathrm{M}$ mustard oil in 5\% DMSO. For each infusion, $3 \mathrm{ml}$ of solution was infused into the colon over 1-2 min. Solutions were drained from the proximal end of the colon at the same rate that they were introduced into the rectum to minimize colon distension during drug infusion. A colon distension series was then performed after infusion of each test solution. The 5\% DMSO control solution was tested before solutions containing capsaicin or mustard oil were infused, to examine vehicle effects on each afferent. At the end of the 10 min testing period, the colon was washed with $10 \mathrm{ml}$ of oxygenated ACSF, and a distension series was run again to ensure that the cell had returned to baseline predrug responses. If effects could not be washed out, the experiment was terminated. In some cases, cells penetration was maintained for over an hour, allowing testing of a single cell with multiple solutions. Presentation order of capsaicin, mustard oil, and acid was varied between cells in which multiple sensitizing agents were delivered. Washout was obtained between each drug, and no significant differences correlated with presentation order were seen.

Application of drugs might produce alterations in colon compliance; changes in mechanical properties of the colon could modulate neuronal response properties. To test this possibility, the amount of fluid needed to maintain constant pressure within the colon was measured at each distension pressure for each drug infusion. We tested colon compliance by serially individually infusing each of the drugs used in this study in the order that was used for physiological recording experiments: ACSF, 5\% DMSO, $1 \mu \mathrm{M}$ capsaicin (in 5\% DMSO), $100 \mu \mathrm{M}$ mustard oil (in 5\% DMSO), ACSF (to wash out drugs and DMSO), and ACSF, pH 4. Distension series were run four times in the presence of each drug, and the results were averaged.

Data analysis. For each cell, the resting membrane potential, conduction velocity, spike amplitude, action potential duration at $50 \%$ of peak amplitude, and amplitude and duration of the afterhyperpolarization was determined as described previously (Bielefeldt et al., 2006). To generate stimulus response functions, both the mean action potential frequency for the entire stimulation period and maximal instantaneous frequency were determined for each distension pressure.

Immunohistological analysis of recorded cells. At the end of the experiment, the L6 DRG was removed and immersion fixed [4\% paraformaldehyde in $0.1 \mathrm{M} \mathrm{PB}$ (in mM: $12.5 \mathrm{NaH}_{2} \mathrm{PO}_{4}, 87.5 \mathrm{Na}_{2} \mathrm{HPO}_{4}$ ) for $20 \mathrm{~min}$ at $25^{\circ} \mathrm{C}$. Ganglia were then embedded in $10 \%$ gelatin, postfixed in $4 \%$ paraformaldehyde for $30 \mathrm{~min}$, followed by cryoprotection in $20 \%$ sucrose for at least $1 \mathrm{~h}$. Frozen sections $(35 \mu \mathrm{m})$ were collected serially in PB and reacted with CY2-tagged avidin to label Neurobiotin-filled cells (Vector). Each section was stained with rabbit anti-TRPV1 (Neuromics), and goat anti-GFR $\alpha 3$ (R\&D Systems). After incubation in primary antiserum, tissue was washed and incubated in donkey anti-rabbit and donkey anti-goat secondary antiserum (conjugated to CY3 or CY5, respec- 


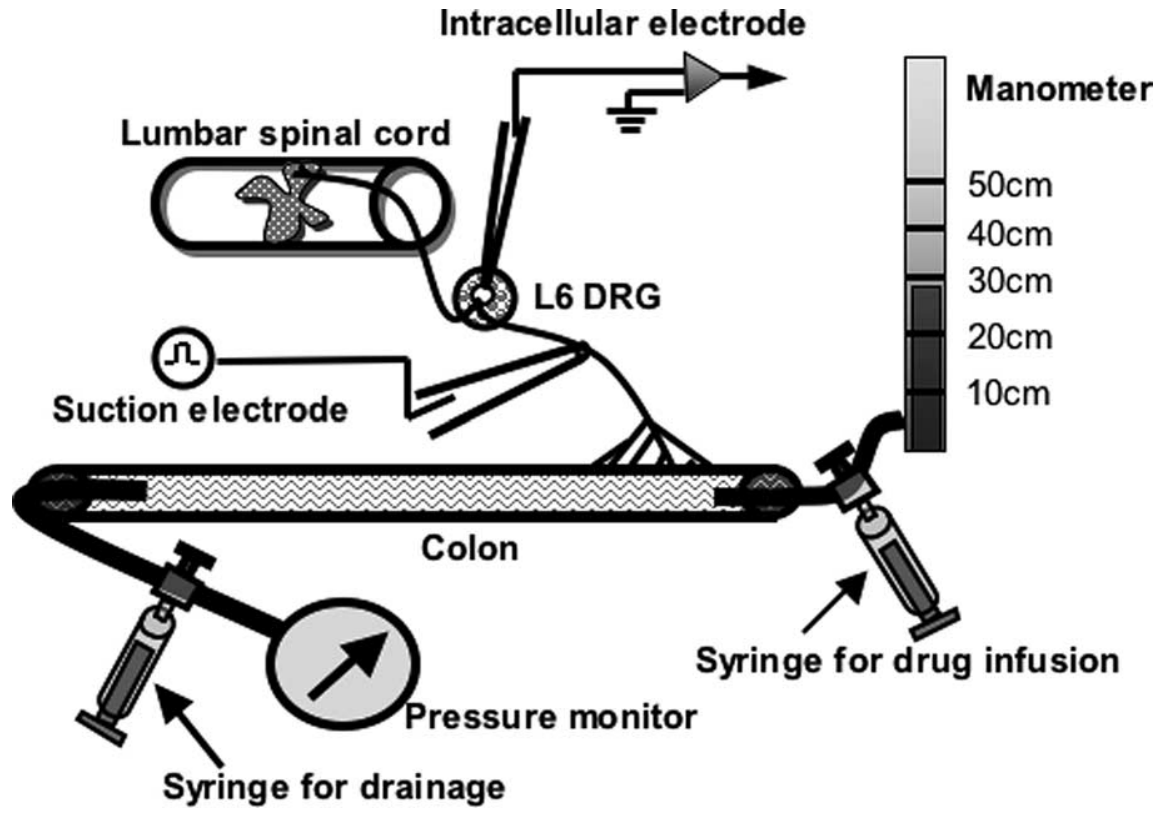

Figure 1. Schematic for ex vivo recording setup. Mouse colon, pelvic nerve, L6DRG, and spinal cord were dissected contiguously and placed in the recording dish. \#50 PE tubing was used to connect the distal end of the colon to a manometer filled with either ACSF or drug solution. A syringe placed between the manometer and the distal end of the colon allowed infusion of drugs into the colon. A second syringe at the proximal end of the colon allowed removal of solutions to minimize colonic distension during drug instillation and washout. The proximal end of the colon was attached to a pressure monitor to record changes in colonic pressure during experiments.

tively, diluted 1:500; Molecular Probes). Distribution of fluorescent staining was determined using an Olympus confocal microscope and sequential scanning to prevent bleedthrough of the different fluorophores. Specific staining for both antibodies was tested on DRG tissue from appropriate TRPV $1^{-/-}$or GFR $\alpha 3^{-/-}$mice. No staining for either antibody was observed in knock-out tissue (Fasanella et al., 2008).

Statistical analysis. All physiology data are mean \pm SE. Results were analyzed using the Mann-Whitney rank sum test, a two-way ANOVA, or Fisher's exact test where appropriate. A value of $p<0.05$ was considered statistically significant.

\section{Results}

Basic properties of colon afferents

For these studies, we used a novel ex vivo electrophysiology preparation in which recordings were obtained from sensory neuron cell bodies in the L6 spinal ganglion in response to stimulation of the colon with fluid distension or von Frey probing. The preparation is described in Figure 1. A total of 127 colon afferents were identified by response to colon distension and/or probing of the colon with von Frey hairs. In addition, action potentials were recorded from 221 afferents electrically stimulated by the pelvic nerve suction electrode, but that were nonresponsive to colon stimulation (nonresponsive afferents). All colon afferents conducted in the C-fiber range (conduction velocity, $\leq 0.41 \mathrm{~m} / \mathrm{s}$ ); no difference in conduction velocity was observed between colon and nonresponsive pelvic afferents (Table 1). Most colorectal afferents were quiescent at rest; only 20\% (27 of 127) of colon sensory neurons were spontaneously active (mean spontaneous firing rate, $1.5 \pm 0.1 \mathrm{~Hz}$ ). Sixty-six percent (51 of 77) of colon afferents responded to von Frey probing; the average threshold for response was $4.1 \pm 0.1 \mathrm{~g}$. All colon afferents responsive to von Frey probing also responded to colon distension.

Action potential shape was not significantly different between all colon afferents and nonresponsive pelvic afferents. However, classification of colon afferents by response to distension as HF and LF afferents (see below) revealed significant differences in action potential shape. Action potentials recorded from $\mathrm{HF}$ afferents were of significantly $(p<$ $0.05)$ briefer duration than those recorded from LF afferents [action potential duration at half-amplitude $\left(\mathrm{APD}_{50}\right)$ : $\mathrm{HF}$, $1.81 \pm 0.1 \mathrm{~ms} ; \mathrm{LF}, 2.3 \pm 0.1 \mathrm{~ms}]$. This difference, illustrated in Figure 2, may underlie the higher firing rates seen in $\mathrm{HF}$ cells (Hille, 2001). Previous studies in cutaneous afferents have demonstrated a link between somal action potential shape and sensory receptive field properties, although the precise channel mechanism is unknown (Fang et al., 2005, 2006).

\section{Responses to colorectal distension}

All 127 colon afferents encoded stimulus intensity over the entire suprathreshold range of colon distension tested. Based on the stimulus response profile to colon distensions from 10 to $40 \mathrm{cmH}_{2} \mathrm{O}$, two distinct populations of afferents could be distinguished. The first group contained afferents that responded to colon distension with high-frequency action potential firing. These were characterized as $\mathrm{HF}$ cells. Responses obtained from a representative HF colon afferent are shown in Figure 2. The Neurobiotin-labeled cell body of the HF afferent (Fig. $2 A$, green) was identified as negative for the ion channel TRPV 1 (Fig. 2A, red) and the growth factor receptor GFR $\alpha 3$ (Fig. $2 A$, blue) expression by post hoc immunocytochemistry. In HF cells, maximal colon distensions $\left(40 \mathrm{~cm} \mathrm{H}_{2} \mathrm{O}\right)$ elicited action potential firing at rates $>20 \mathrm{~Hz}$ (Fig. $2 \mathrm{~B}$ ). Responses in $\sim 50 \%$ of $\mathrm{HF}$ cells showed significant adaptation of firing rate during colon distension, such that the firing rate at end of $20 \mathrm{~s}$ of colon distension (terminal firing rate) was $<50 \%$ of the peak firing rate. Firing rate adaptation in HF cells was $9.5 \pm 1.1 \mathrm{~Hz}$ or $48 \pm 5 \%$ (terminal firing rate/peak firing rate).

The second group of colon afferents responded to colonic distension with low-frequency action potential firing. These were characterized as LF cells, and responses obtained from a representative LF colon afferent are shown in Figure 2. Post hoc immunohistochemical examination of this LF afferent (Fig. $2 B$, green) identified this cell as TRPV1 (Fig. $2 B$, red) and GFR $\alpha 3$ (Fig. $2 B$, blue) expressing. Although maximal colonic distension (40 $\mathrm{cmH}_{2} \mathrm{O}$ ) elicited robust action potential firing in LF cells, action potential firing rates were much slower $(<10 \mathrm{~Hz})$ than those recorded in HF cells in response to the same distension stimulus (Fig. 2, compare $A, B$ ). Responses in $70 \%$ of LF cells showed little or no adaptation of firing rate during the $20 \mathrm{~s}$ colonic distension stimulus. Average response adaptation in all LF cells was $1 \pm 0.1$ $\mathrm{Hz}$, significantly $(p>0.001)$ less than that seen in the HF population. However, percentage adaptation in LF cells [62 $\pm 4 \%$ (terminal firing rate/peak firing rate)] is similar to that seen in $\mathrm{HF}$ cells, which likely reflects the difference in firing rate and dynamic range. The adaptation differences between LF and HF cells are difficult to interpret without knowing the pattern of connections to second-order neurons and contribution(s) of each class of colon afferents to the overall perception of visceral pain.

An examination of the instantaneous action potential firing 
Table 1. Distention-responsive colon afferents are divided into functionally distinct classes, LF and HF

\begin{tabular}{|c|c|c|c|}
\hline & LF colon afferents $(n=82)$ & HF colon afferents $(n=33)$ & Nonresponsive (pelvic) afferents $(n=221)$ \\
\hline Conduction velocity $(\mathrm{m} / \mathrm{s})$ & $0.38 \pm 0.02$ & $0.41 \pm 0.02$ & $0.38 \pm 0.01$ \\
\hline $\mathrm{APD}_{50}(\mathrm{~ms})$ & $2.27 \pm 0.11^{*}$ & $1.81 \pm 0.11$ & $2.46 \pm 0.06^{*}$ \\
\hline Action potential amplitude (APA) (mV) & $62.2 \pm 1.6$ & $59.4 \pm 0.5$ & $60.7 \pm 0.9$ \\
\hline Afterhyperpolarization amplitude (mV) & $12.0 \pm 0.9$ & $13.9 \pm 0.3$ & $14.1 \pm 0.5$ \\
\hline No. of cells TRPV1-positive & $25 / 29$ & $4 / 23$ & n.d. \\
\hline No. of cells GFR $\alpha 3$-positive & $12 / 29$ & $3 / 23$ & n.d. \\
\hline Mean threshold $\left(\mathrm{cmH}_{2} \mathrm{O}\right)$ & $17.5 \pm 1.1^{* *}$ & $2.6 \pm 0.4$ & n.d. \\
\hline Mean firing rate, $20 \mathrm{CmH}_{2} \mathrm{O}(\mathrm{Hz})$ & $0.67 \pm 0.07^{* *}$ & $4.30 \pm 0.70$ & n.d. \\
\hline Mean firing rate, $40 \mathrm{cmH}_{2} \mathrm{O}(\mathrm{Hz})$ & $1.41 \pm 0.11^{* *}$ & $10.22 \pm 0.61$ & n.d. \\
\hline Maximum firing rate, $20 \mathrm{cmH}_{2} \mathrm{O}(\mathrm{Hz})$ & $2.16 \pm 0.21^{* *}$ & $10.98 \pm 1.51$ & n.d. \\
\hline Maximum firing rate, $40 \mathrm{cmH}_{2} \mathrm{O}(\mathrm{Hz})$ & $4.55 \pm 0.30^{* *}$ & $23.53 \pm 1.43$ & n.d. \\
\hline No. von Frey responders & $40 / 63$ & $11 / 14$ & n.d. \\
\hline \multirow[t]{2}{*}{ von Frey threshold $(\mathrm{g})$} & $3.09 \pm 0.08^{*}$ & $1.17 \pm 0.21$ & n.d. \\
\hline & $5 / 9$ respond & $3 / 9$ respond & n.d. \\
\hline \multirow[t]{2}{*}{$1 \mu \mathrm{m}$ capsaicin } & $8 / 9$ sensitized & $3 / 9$ sensitized & n.d. \\
\hline & $9 / 12$ respond & 2/7 respond & n.d. \\
\hline \multirow[t]{2}{*}{$100 \mu \mathrm{m}$ mustard oil } & 10/12 sensitized & 2/7 sensitized & n.d. \\
\hline & $5 / 6$ respond & 1/6 respond & \\
\hline $\mathrm{pH} 4.0$ & $5 / 6$ sensitized & 1/6 sensitized & n.d. \\
\hline
\end{tabular}

Most action potential properties of colon afferents, such as conduction velocity, action potential amplitude, and action potential afterhyperpolarization, are not different from those seen in pelvic afferents not responsive to colon stimulation. Most distension-responsive colon afferents are LF cells, defined by significantly lower firing rates and higher response thresholds to colonic distension than seen in $\mathrm{HF}$ cells. LF afferents also have significantly longer duration action potentials and higher mechanical thresholds than do HF cells. In addition, TRPV1 and GFR $\alpha 3$ are predominantly expressed in LF colon afferents, and these cells are significantly sensitized by capsaicin, mustard oil, and low pH. Values are mean \pm SEM. ${ }^{*} * * * 0.05,0.001$ versus HF afferents. n.d., Values not determined.

rate elicited by maximal $\left(40 \mathrm{cmH}_{2} \mathrm{O}\right)$ colon distension revealed two statistically distinct populations of colon afferents. Each population is a Gaussian distribution with a shared boundary at $\sim 10$ $\mathrm{Hz}$ (Fig. 3). In subsequent analyses, the action potential response elicited by maximal $\left(40 \mathrm{cmH}_{2} \mathrm{O}\right)$ colon distension was used to classify cells as HF or LF colon afferents. Most colon afferents ( 89 of 127) were characterized as LF cells; $30 \%$ of colon afferents were characterized as HF cells. Interestingly, LF cells appeared to have elevated distension response thresholds to action potential firing (Fig. 2, compare $A, B$ ). In fact, most LF cells did not respond to the mildest distension used in this study $\left(10 \mathrm{cmH}_{2} \mathrm{O}\right)$, whereas this stimulus was sufficient to elicit action potential firing in nearly all HF cells. Most (36 of 38) HF cells had measured thresholds of $10 \mathrm{cmH}_{2} \mathrm{O}$ distension, whereas most (70 of 90) LF cells had measured thresholds of $20,30,40$, or $50 \mathrm{cmH}_{2} \mathrm{O}$ distension.

To examine absolute distension thresholds in these two populations of neurons, we conducted regression analysis for each colon afferent using the linear region of the mean firing response to the distension series (Sengupta and Gebhart, 1994a). The calculated absolute distension response thresholds for all cells examined are shown in Figure $4 A$; measured minimal distensions $\left(10,20,30\right.$ or $\left.40 \mathrm{cmH}_{2} \mathrm{O}\right)$ required to elicit unit response are also given (Fig. $4 \mathrm{~A}$, inset). Analysis of absolute threshold revealed that colon afferents that coded maximal colon distension with firing frequencies $>10 \mathrm{~Hz}$ (HF cells) had mean response thresholds of $2.6 \pm 0.4 \mathrm{cmH}_{2} \mathrm{O}$, whereas those cells with maximal firing frequencies $<10 \mathrm{~Hz}$ (LF) had mean thresholds of $17.5 \pm 1.1$ $\mathrm{cmH}_{2} \mathrm{O}$. Both measured (Fig. $4 \mathrm{~A}$, inset) and absolute (Fig. 4A) thresholds differ significantly between $\mathrm{HF}$ and LF colon afferents $(p<0.001)$. These data suggest that HF and LF cells may be further characterized as low (HF) and high (LF) threshold cells.

This difference in action potential firing pattern is not simply attributable to a difference in threshold between LF and HF afferents. Maximal instantaneous firing rates elicited by each distension pressure were determined to define the stimulus response function for LF and HF cells. These data are shown in Figure $4 B$. Firing frequencies recorded from $\mathrm{HF}$ and LF afferents were significantly different at each distension pressure $(p<0.001)$ (Fig.
$4 B)$. Interestingly, colon distensions to much higher pressures $\left(>50 \mathrm{cmH}_{2} \mathrm{O}\right)$ did not elicit action potential firing in LF afferents comparable with firing rates recorded in HF afferents (data not shown), suggesting that LF cells are functionally distinct from $\mathrm{HF}$ cells. We propose that distension-sensitive colon afferents are functionally divided into two classes: HF cells, characterized by high firing rates, low response thresholds, and brief action potential durations; and LF cells, characterized by low firing rates, high response thresholds, and longer action potential durations.

\section{Physiological characteristics of TRPV1-positive cells}

A total of 52 colon afferents characterized by distension response was subsequently Neurobiotin-filled and recovered for immunohistochemical analysis. Cells were examined for expression of the capsaicin receptor, TRPV1, a nonselective ion channel shown previously to define a subset of nociceptors and implicated in heat and inflammatory pain (Caterina et al., 1997, 2000). Expression of GFR $\alpha 3$, the specific receptor for artemin, a member of the GDNF (glial cell line-derived neurotrophic factor) family of growth factors (Baloh et al., 1998), was also examined in colon afferents. We previously showed that artemin potently sensitizes TRPV1 channels in vitro and in vivo (Malin et al., 2006). Thirtytwo cells were TRPV1-positive, and 20 were TRPV1-negative (Fig. 2, Table 1). GFR $\alpha 3$ was not observed in any TRPV1negative neuron; however, 50\% of the TRPV1-positive afferents also expressed GFR $\alpha 3$.

Most (86\%) LF afferents expressed TRPV1 immunoreactivity, but few (13\%) HF afferents were TRPV1 positive; these differences were highly significant $(p<0.001)$. Consistent with this correlation between LF/HF cell type and TRPV1 expression, most (29 of 32) TRPV1-positive afferents had higher distension thresholds and responded to $20,30,40$, or $50 \mathrm{cmH}_{2} \mathrm{O}$ distension, whereas most (17 of 20) TRPV1-negative afferents responded to the lowest distension pressures $\left(5\right.$ or $10 \mathrm{cmH}_{2} \mathrm{O}$ ), as well as to more noxious stretch stimuli.

Both absolute (Fig. 5A) and measured (Fig. 5A, inset) distension response thresholds were significantly $(p<0.001)$ higher in TRPV1-expressing afferents (TRPV1-positive, $12.5 \pm 1.4$ 

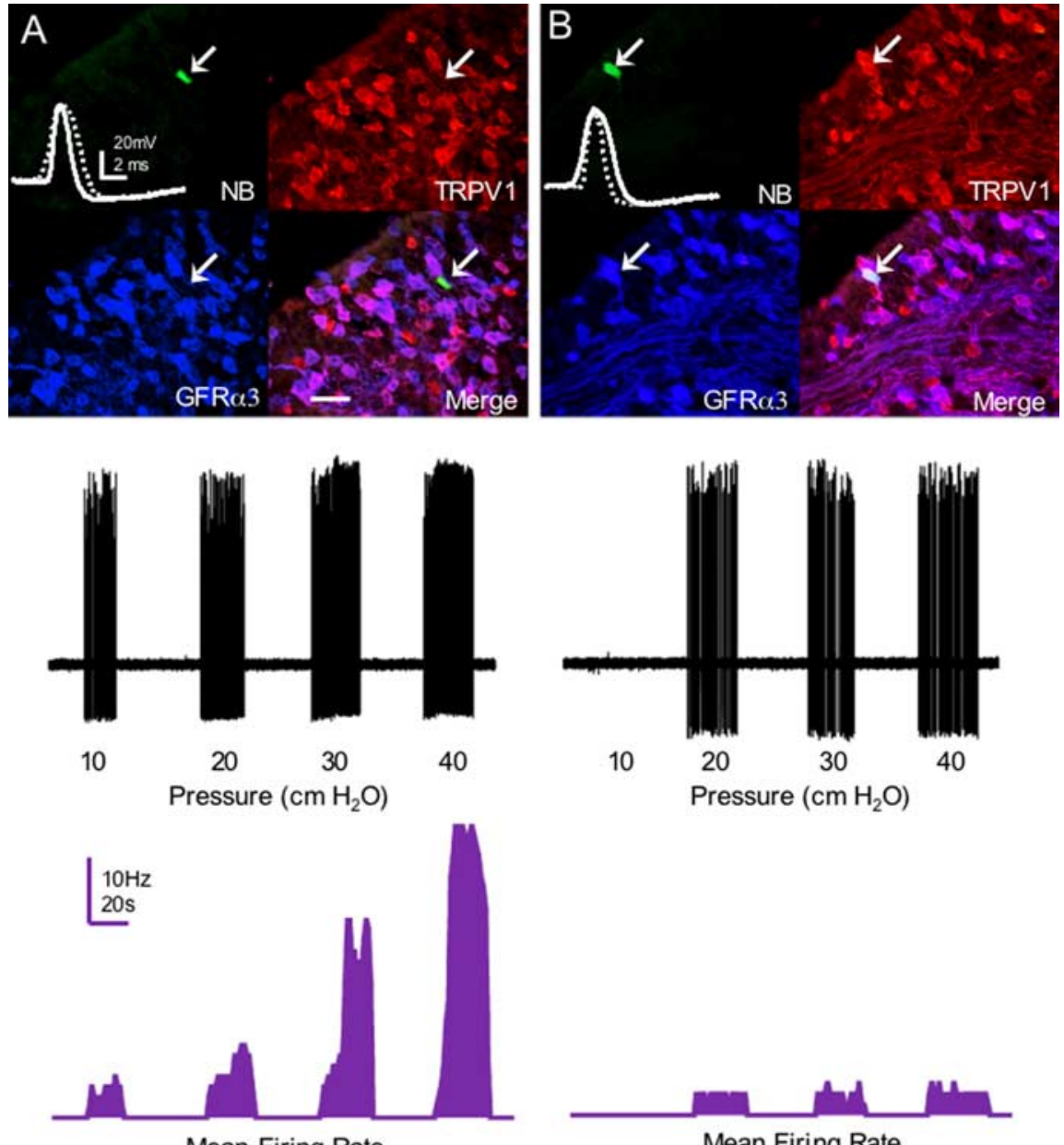

Mean Firing Rate

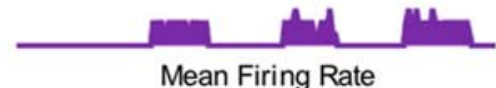

Figure 2. Colon afferents have distinct neurochemistry and response properties. A, Some colon afferents (HF) typically responded to the lowest pressure tested $\left(10 \mathrm{cmH}_{2} 0\right)$, coded stimulus intensities, fired at high frequency, and exhibited adaptation (see mean firing rate, graphed below trace). HF cells had briefer action potential durations (solid trace inset) compared with other (LF) afferents (dashed trace inset). Eighty-seven percent of immunochemically identified HF cells were TRPV1- and GFR $\alpha 3$ negative (panel at right). $\boldsymbol{B}$, However, most afferents (LF) had higher distension response thresholds, rarely fired $>5 \mathrm{~Hz}$, and showed little adaptation of firing rate during the distension stimulus (see mean firing rate, graphed below trace). LF cells had longer action potential durations (solid trace inset) compared with HF afferents (dashed trace inset). Eighty-seven percent of LF afferents were TRPV1-positive. Scale bar, $20 \mu \mathrm{m}$.

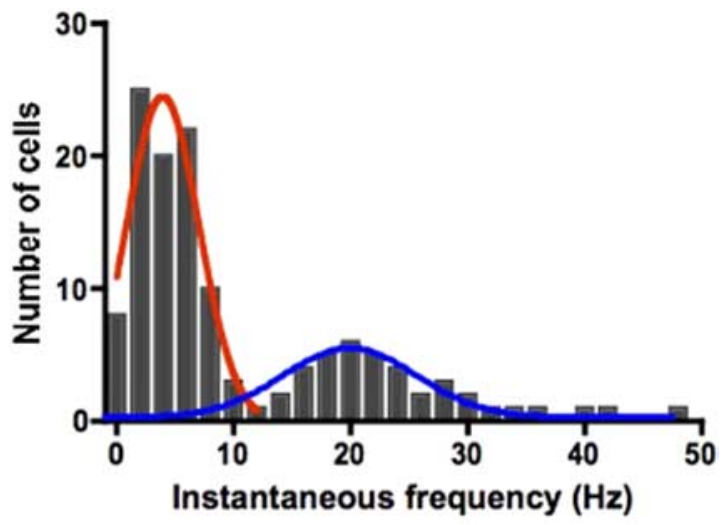

Figure 3. Two distinct populations of colonic afferents were identified based on firing frequency. Examination of instantaneous firing frequencies elicited by maximal $\left(40 \mathrm{cmH}_{2} \mathrm{O}\right)$ colon distension revealed two distinct populations of colon afferents. Both populations were Gaussian distributions and were significantly different from one another $(p<0.001)$. Cells exhibiting a response frequency $>10 \mathrm{~Hz}$ were defined as $\mathrm{HF}$; those with responses $<10 \mathrm{~Hz}$ were defined as LF afferents.
$\mathrm{cmH}_{2} \mathrm{O} ; \quad$ TRPV1-negative, $3.6 \pm 0.8$ $\mathrm{cmH}_{2} \mathrm{O}$ ). In addition, TRPV1-expressing colon afferents respond to colon distension with significantly $(p<0.001)$ lower rates of action potential firing than do TRPV1-negative afferents at all pressures examined (at $40 \mathrm{cmH}_{2} \mathrm{O}$ : TRPV1-positive, $7.3 \pm 1.3 \mathrm{~Hz}$; TRPV1-negative, $21.7 \pm 2.1$ $\mathrm{Hz}$ (Fig. 5B). Seventy-five colon afferents were physiologically characterized but not immunohistochemically identified (Table 1). Sixty-five percent would be categorized as LF afferents based on the action potential firing response to maximal colon distension (Fig. 5B). Interestingly, this is the same percentage of colon afferents that have been demonstrated to express TRPV1 in immunohistochemical studies (Christianson et al., 2006b). Together, these data suggest that TRPV1 expression occurs primarily in LF afferents.

\section{Sensitization of colon afferents by protons, capsaicin, and mustard oil} In experiments in isolated sensory neurons, we and others have reported that direct application of capsaicin or mustard oil induces action potential firing and/or calcium influx in subsets of sensory neurons (Jordt et al., 2004; Elitt et al., 2006; Akopian et al., 2007). The action(s) of capsaicin and mustard oil are highly correlated to expression of TRPV1 and TRPA1 receptors, respectively. To examine the response properties of intact colon afferents to these compounds, the lumen of the colon was infused with capsaicin and mustard oil at concentrations that, in isolated neurons, have previously been demonstrated to produce receptor-specific responses (Caterina et al., 2000; Jordt et al., 2004; Malin et al., 2006; Akopian et al., 2007). In addition, we tested responses to low $\mathrm{pH}, \mathrm{pH} 4$, because protons are known to activate sensory neurons via acidsensitive channels, such as TRPV1, and members of the acidsensitive ion channel (ASIC) family. Functional expression of both TRPV1 and ASIC family members has been demonstrated in colon afferents (Jones et al., 2005; Page et al., 2005; Christianson et al., 2006a,b; Hughes et al., 2007; Sugiura et al., 2007).

In most cases, an individual cell was tested with more than one stimulus (Table 1). Agonists were given for $5 \mathrm{~min}$, during which time firing activity was recorded to identify direct agonist responses. Then a colon distension series $(10,20,30$, and 40 $\mathrm{cmH}_{2} \mathrm{O}$ ) was applied to evaluate sensitization of distension responses by each agonist. Drugs were washed out with ACSF or vehicle, as appropriate. Only when responses returned to baseline pretreatment levels were additional agonists applied. In addition, stimulus order was varied between cells, and agonist responses did not correlate with the order of drug delivery (see Materials and Methods). Representative data are shown in Figure 6. The colon afferent in the top panel showed sensitization of responses to colon distension after capsaicin, mustard oil, and acid, with complete washout in between application of each drug. (Note 

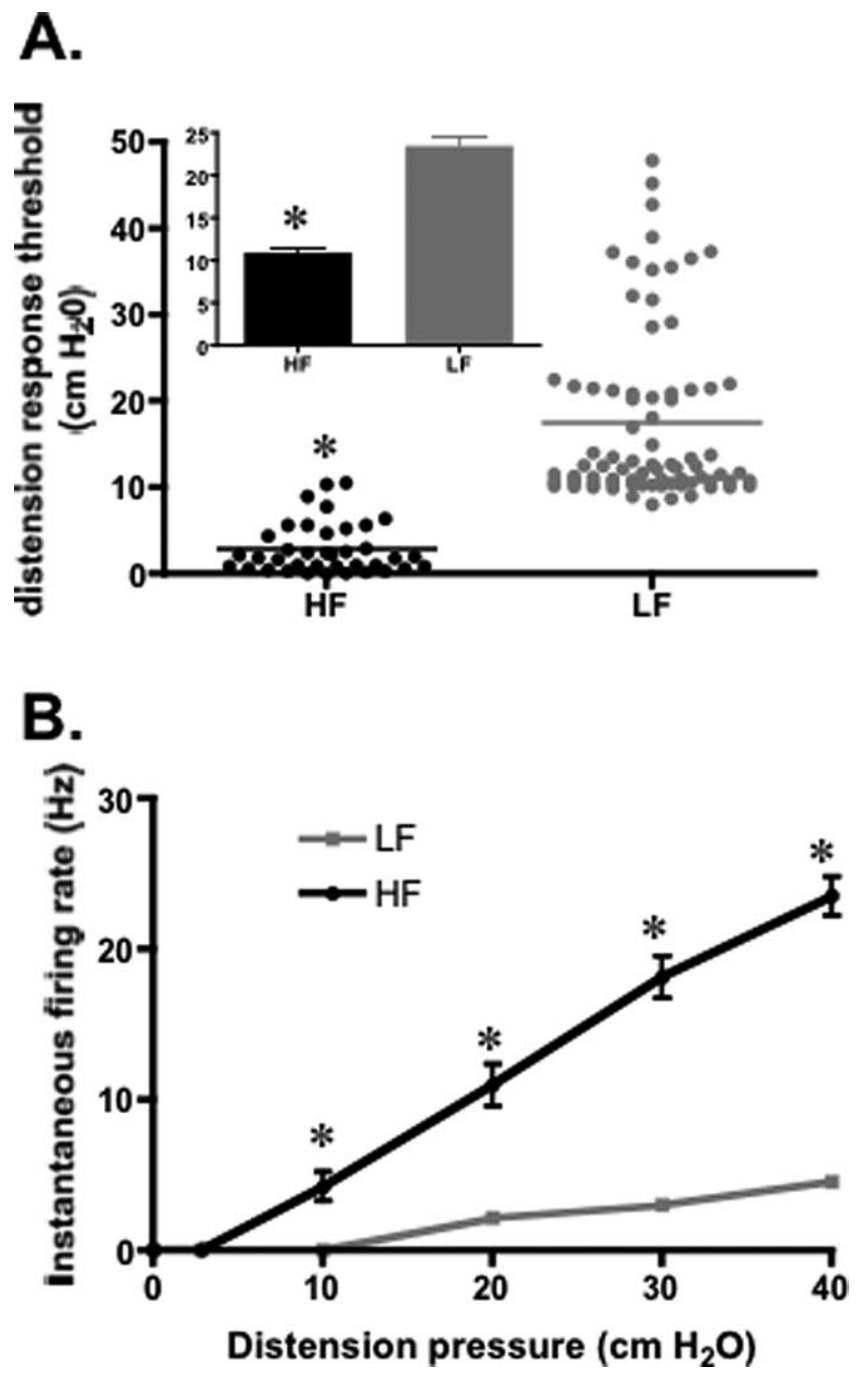

Figure 4. HF colon afferents have lower thresholds and higher stimulus responses than LF cells. $A$, Response to colon distension to $10,20,30$, and $40 \mathrm{cmH}_{2} 0$ was recorded for all cells, and minimal colon distensions required to elicit action potential firing noted. Cells were then separated by maximal instantaneous frequency response into $\mathrm{HF}$ and $\mathrm{LF}$ types. $\mathrm{HF}$ cells have significantly lower measured response thresholds than do LF cells (inset). Absolute distension response thresholds were calculated for all colon afferents by regression analysis, as in previous studies (Sengupta and Gebhart, 1994a). HF colon afferents had significantly lower absolute distension thresholds than seen in LF cells. $\boldsymbol{B}$, Stimulus response function of maximal instantaneous firing frequencies at all distension pressures reveals that both $\mathrm{HF}$ and LF colon afferents encode stimulus intensity. However, $\mathrm{HF}$ afferents respond with significantly greater firing rates than do LF afferents at all distension pressures. This difference is most marked at higher colon distensions, at which there is a fourfold difference in firing rate between HF and LF afferents. Values are mean \pm SEM. ${ }^{*} p<0.001$.

that the direct action potential firing responses to each agonist are not shown here.) Importantly, 5\% DMSO, the vehicle for both capsaicin and mustard oil in these experiments, had little effect on response to colon distension. The cell in the bottom panel also shows little effect of DMSO, but pronounced sensitization of distension responses in capsaicin and low $\mathrm{pH}$. Interestingly, this cell was not sensitized by mustard oil, suggesting that the overlap between TRPV1 and TRPA1 function, although significant, is not complete in colon afferents.

Effect of sensitizing agents on colorectal compliance

Biomechanical properties of the colon might be altered during repeated distension and in response to drug application; the fol-
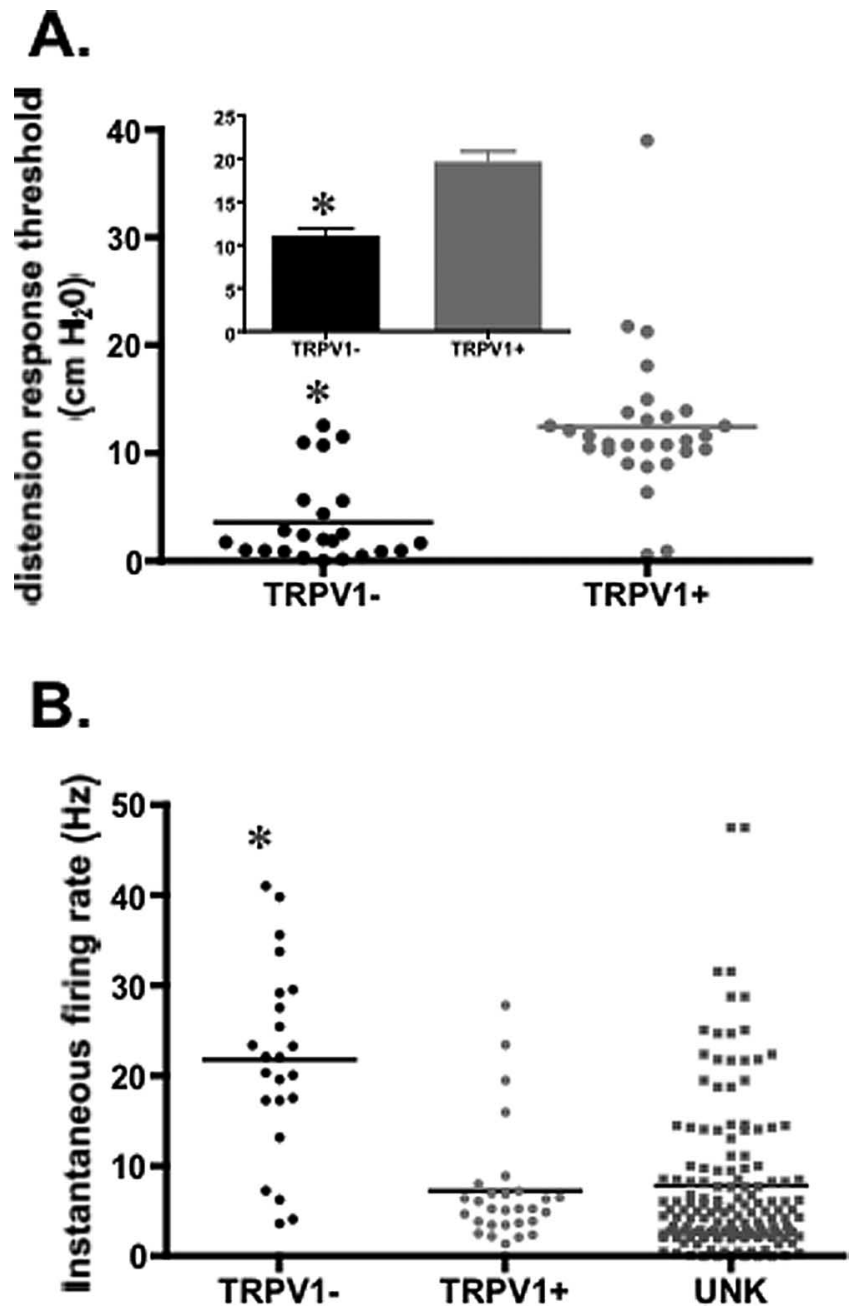

Figure 5. TRPV1-expressing colon afferents have higher thresholds and fire at slower rates than TRPV1-negative neurons. $\boldsymbol{A}$, Distension threshold was measured (inset) and calculated using regression analysis $(\boldsymbol{A})$ as previously. Mean distension thresholds were 3.5 times higher in TRPV1-positive colon afferents, suggesting that TRPV1+ afferents are predominantly LF. $\boldsymbol{B}$, Mean instantaneous firing frequencies elicited by maximal $\left(40 \mathrm{cmH}_{2} 0\right)$ colon distension were three times greater in TRPV1-negative (TRPV1-) afferents, than in TRPV1-positive (TRPV1+) neurons $(p<0.001)$. A total of 75 afferents was functionally characterized, but not immunohistochemically identified in these experiments (UNK). Most of these neurons are classified as $L F$, based on instantaneous firing frequency and response threshold. Together, these data predict that $\sim 65 \%$ of distension-sensitive colonic afferents (most LF afferents) are TRPV1positive. Values are mean \pm SEM. ${ }^{*} p<0.001$.

lowing experiment was performed to address this potential confound. Pressure-volume curves were obtained from four colons tested with repeated distension series in the presence and washout of each agonist. Each colon was tested four times during each agonist and washout to obtain average pressure and volume data. Each colon was tested with six solutions. The sequence of agonist application was identical with that used during a typical electrophysiological experiment. Volume needed to maintain constant colon pressure could be resolved to $0.001 \mathrm{ml}$; data are shown in Table 2 . The volume required to maintain the each pressure was not affected by the presence of any of the agonists or vehicles used in this study. These results indicate that changes in biomechanical properties of the colon were not responsible for the observed changes in neuronal response properties reported in this study. 

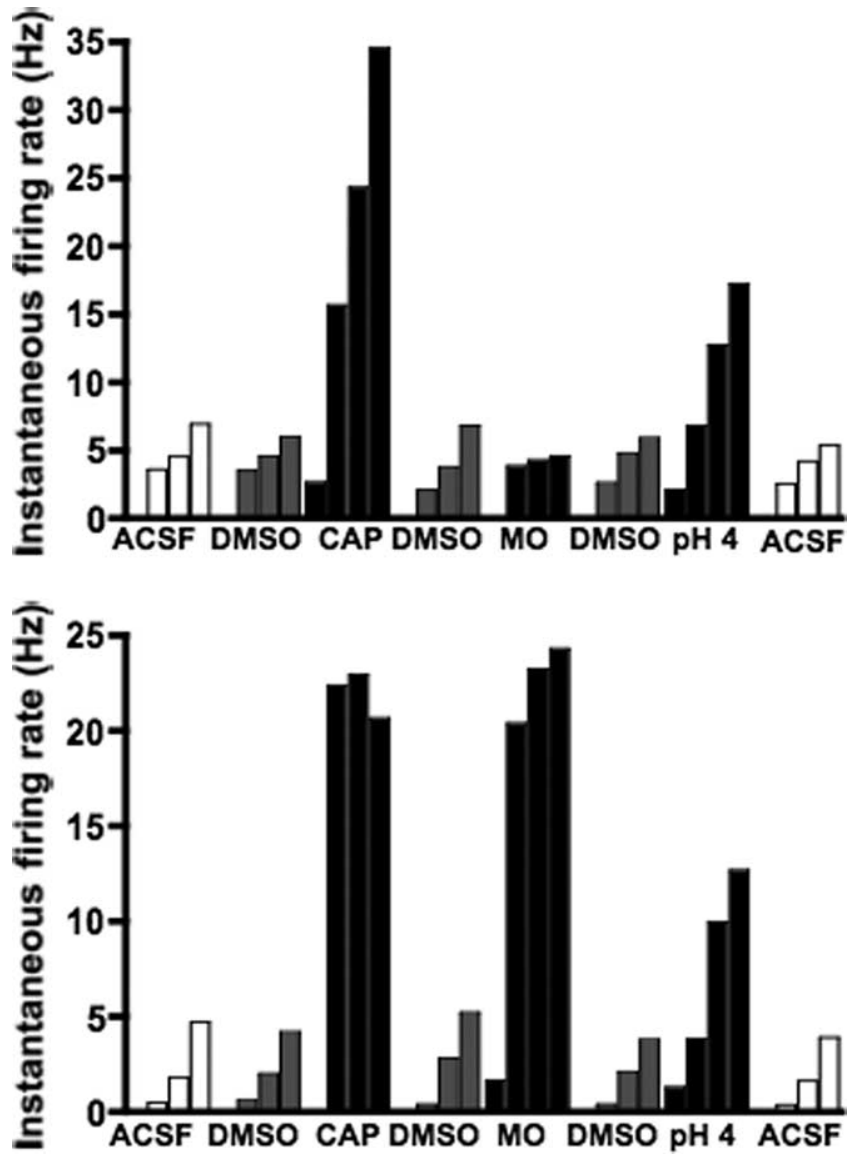

Figure 6. Capsaicin, mustard oil, and acid sensitize colonic afferents. Maximal firing frequencies in two representative sensory afferents elicited by $20 \mathrm{~s}$ colon distension (to 10,20,30, and $40 \mathrm{CmH}_{2} \mathrm{O}$ ) in ACSF, 5\% DMSO, $1 \mu \mathrm{m}$ capsaicin, $100 \mu \mathrm{M} \mathrm{M0}$, and low pH are given. Agonists and vehicle (DMSO) were given sequentially at 10 min intervals as shown. Cells were not sensitized by DMSO alone (compare distension responses elicited in ACSF and DMSO). Furthermore, capsaicin, mustard oil and pH 4 effects showed washout (compare CAP and DMSO). Both cells shown are LF TPV1-positive cells: one cell was sensitized by capsaicin, mustard oil, and low pH (bottom) as were most LF cells tested, whereas the other was sensitized by capsaicin and low $\mathrm{pH}$, but not by mustard oil (top).

Actions of capsaicin, mustard oil, and low $\mathrm{pH}$ are restricted to TRPV1-expressing neurons

Colon afferents were classified as responders for a given agonist if, after agonist application, cells fired action potentials or showed an increase (more than twofold of that seen before drug application) in ongoing activity (Table 1). Neurons were classified as "sensitized" if no direct firing response to drug application was seen, but if cells did show enhanced responses to subsequent colon distension (Table 1). Our analysis shown in Figure $5 B$ demonstrated that TRPV1 is expressed by the majority of LF afferents. Previous studies have suggested that TRPA1 is expressed in a subset of TRPV1-expressing sensory neurons (Bandell et al., 2004; Jordt et al., 2004). Based on these observations, we expected capsaicin and mustard oil responses primarily in LF colon afferents. However, although more LF than HF cells responded to capsaicin and acid, these differences were not significant, probably because of the small number of cells tested. However, mustard oil sensitized LF significantly more often than HF neurons.

All of the pharmacologically tested neurons were also examined for TRPV1 expression. All cells "responding" and/or "sensitized" by mustard oil, capsaicin, or acid expressed TRPV1. Capsaicin, mustard oil, and acid application to the colon each induced significant direct responses in the majority of TRPV1expressing afferents (in Hz: CAP, $5.0 \pm 2$; MO, $5.5 \pm 2$; acid, $3.3 \pm 2$ ) (Table 1). Only one cell classified as a "responder" was spontaneously active before drug application $(2.2 \mathrm{~Hz})$. Direct responses to TRPV1 and TRPA1 agonists were not seen in TRPV1-negative afferents. The majority of these affected cells were LF afferents. Interestingly, the few LF afferents that were not modulated by capsaicin, mustard oil, and low $\mathrm{pH}$ did not express TRPV1. TRP agonist modulation was seen in a few HF afferents. Three of nine HF afferents exposed to capsaicin exhibited both de novo action potential firing and increased responses to colon distension. Two of these cells were also activated and sensitized by mustard oil and one was activated and sensitized by low $\mathrm{pH}$. All three of these cells expressed TRPV1.

Absolute colon distension thresholds calculated before and after agonist application for all cells are given in Figure 7, left. Capsaicin, mustard oil, and low $\mathrm{pH}$ reduced absolute colon distension thresholds in nearly all TRPV1-expressing afferents. Importantly, DMSO, the vehicle for capsaicin and mustard oil delivery, did not alter absolute colon distention thresholds (Fig. 7, bottom left). TRPV1-expressing afferents showed significant sensitization to colon distention after capsaicin application. This was evident at all distension pressures (Fig. 7, right). These data suggest that the effects of capsaicin recorded in this study are direct effects on sensory afferents and do not arise from TRPV1 expression in enteric neurons or non-neuronal structures of the colon. Mustard oil also sensitized responses to colon distension in TRPV1-expressing afferents at higher distension pressures $\left(>10 \mathrm{cmH}_{2} \mathrm{O}\right)$ (Fig. 7). As with capsaicin, mustard oil effects were also restricted to TRPV1-expressing colon afferents. This result suggests that TRPA1 is expressed in most TRPV1-expressing cells. Low $\mathrm{pH}$ effects were less dramatic that those seen after capsaicin or mustard oil application (Fig. 6, compare capsaicin and acid responses), but sensitization was significant $(p<0.001)$ at higher $\left(>20 \mathrm{cmH}_{2} \mathrm{O}\right)$ distension pressures (Fig. 7). Sensitizing effects of low $\mathrm{pH}$ were also restricted to TRPV1-expressing neurons. This result suggests that TRPV1-expressing neurons are the primary acid sensors for the colon.

\section{Discussion}

The primary goal of these studies was to characterize colon afferents using an approach that combined functional electrophysiology, immunohistochemistry, and pharmacology. We developed a novel preparation to record intracellularly from intact colon afferents, similar to that used by Bielefeldt et al. (2006) to characterize gastric afferents. In this study, we identified HF and LF colon afferents. HF afferents fired at high frequencies in response to colon distension and had low distension thresholds and significantly briefer action potential durations than LF cells. However, $\mathrm{HF}$ afferents were less numerous than HF cells. Interestingly, the HF and LF populations of colon afferents described here had many of the same properties described previously for lowthreshold and high-threshold afferents, respectively. HF afferents in the present study are similar to low-threshold fibers in previous studies; LF afferents had high thresholds and low firing frequencies similar to previously described high-threshold afferents (Sengupta and Gebhart, 1994a; Gebhart, 1999; Rong et al., 2002; Daly et al., 2007).

We did note several differences between these results and previous studies of visceral afferents. First, despite recording from 127 colon afferents, we did not observe fibers conducting in the myelinated range $(>1.0 \mathrm{~m} / \mathrm{s})$. This is contrast to previous reports in rats, in which $\sim 10 \%$ of colon afferents are A $\delta$ fibers (Sengupta 
and Gebhart, 1994a). The differences between these results and the present study could be attributable to species differences. Second, in this study, we observed a relatively low number of spontaneously active colon afferents, whereas previous studies have reported significant numbers of fibers with ongoing activity. The reason(s) underlying these differences are not clear but may be attributable to species differences between rats and mice, different models of colon stimulation, and different electrophysiological preparations. Some previous studies have used balloon distension; the constant presence of the balloon in the colon may have elicited baseline afferent activation (Sengupta and Gebhart, 1994a). However, spontaneous activity was also common in a study of mouse jejunal afferents in which distension was produced by injection of fluid, as in this study. However, the recordings were made from teased fibers (compared with intact neurons in our study) and this may have contributed to the greater appearance of spontaneous activity (Rong et al., 2004). Lynn and Blackshaw (1999) also reported a greater number of spontaneously active fibers using a teased fiber preparation. However, in addition to the different recording site (axon vs soma), in the previous study the colon was opened along the longitudinal axis to allow stimulation of the mucosal surface. It is possible that this procedure sensitized or damaged afferent endings, producing the observed ongoing activity. The prevalence of spontaneous activity in vivo is of significant interest because ongoing activity has been proposed to underlie efferent effects of sensory fibers on the target tissue (Holzer, 2006).

Previous studies have reported that $20-25 \%$ of distensionresponsive colon afferents have high response thresholds to colon distension (Sengupta and Gebhart, 1994a,b). In contrast, we report $\sim 65 \%$ of distension-responsive afferents are high-threshold low-firing rate fibers (LF). There are several possible reasons for this difference. First, the previous studies were performed in vivo and recordings were obtained from teased pelvic nerve fibers. In this study, recordings were obtained in an ex vivo preparation using intracellular electrodes to record from intact sensory neurons. Cutting and teasing the pelvic nerve may have altered the response properties of those afferents, compared with intact afferents. Second, the previous studies were performed in rats, whereas those reported here were performed in mice. Recently, we reported that the distribution and neurochemical phenotype of colon afferents in mice and rats is significantly different (Christianson et al., 2007), suggesting that there may be functional differences in colon afferents between these species as well. Finally, in our preparation, the mechanics of colon distension may be significantly altered from those reported in in vivo experiments. In the ex vivo preparation described here, it is likely that the colon responds to the same distension pressure with greater expansion and stretch than seen in situ, because the supporting pelvis and abdominal structures have been dissected away. This supranormal stretch may excite neurons normally silent, but recruited in injury or disease states. In support of this possibility, we found that LF afferents are activated and sensitized by TRP channel activation, suggesting that these cells are likely to be sensitized by inflammatory mediators, growth factors, and nucleotides (Malin et al., 2006, 2008; Dai et al., 2007; Andersson et al., 2008; CruzOrengo et al., 2008). This property suggests that some LF afferents in our study may be converted from silent afferents in vivo.
Alternatively, in previous studies from other laboratories, the high proportion of HF fibers could be attributable, at least in part, to conversion of LF into HF fibers via sensitization by various stimuli. Thus, there may be continuum in response properties of LF/TRPV1-positive neurons; many may be silent until converted by noxious stimuli, at which point they assume the properties of LF or HF afferents depending on the intensity of noxious stimuli and/or environment.

Our initial emphasis on TRPV1 was based on a number of studies demonstrating that the majority of colon afferents are TRPV1-positive (Robinson et al., 2004; Brierley et al., 2005; Christianson et al., 2006a,b). In addition, previous studies of bladder and colon afferents suggested a functional role for TRPV1 in visceral mechanosensation. Altered micturation was reported in TRPV $1^{-1-}$ mice; however, because the TRPV1 channel is also expressed in the bladder urothelium, the role of TRPV1 in the primary afferent is unclear (Birder et al., 2002; Birder, 2006). Interestingly, both $\mathrm{TRPV} 1^{-/-}$and $\mathrm{ASIC} 3^{-/-}$mice have decreased visceromotor responses to colorectal distension (Jones et al., 2005). This result suggests that TRPV1 plays an important functional role in the response to colon distension, but the afferent populations affected (high or low threshold) by the removal of TRPV1 is unknown. Recent studies have revealed a requirement of TRPV1 expression for development of colon hypersensitivity in mice treated with intracolonic zymosan (Jones et al., 2007). Interestingly, zymosan treatment does not produce overt inflammation, but did cause long-lasting behavioral hypersensitivity. This suggests that, at least for visceral tissues, TRPV1 is necessary for hyperalgesia produced by both inflammatory and noninflammatory insults. Thus, TPRV1-expressing afferents may play a general role in plastic processes associated with persistent visceral pain states.

Although TRPV1 is expressed in hypersensitive afferents after inflammation, it is important to note that these afferents also express other channels and receptors shown previously to contribute to hypersensitivity. In mice, most TRPV1-positive afferents also express TRPA1, and like TRPV1, ablation of TRPA1 reduces development of inflammatory hyperalgesia (Bautista et al., 2006; Kwan et al., 2006). In addition, 80\% of TRPV1-positive fibers express receptors for NGF (trkA) (Orozco et al., 2001) and $\sim 90 \%$ express the specific receptor for artemin (GFR $\alpha 3$ ) (Orozco et al., 2001; Malin et al., 2006). Expression of these growth factors has been shown to increase in inflamed tissues (Weskamp and Otten, 1987; Donnerer et al., 1992; Woolf et al., 1994; Malin et al., 2006) and injection of these growth factors alone produces significant prolonged hypersensitivity (Lewin et al., 1994; Dyck et al., 1997; Malin et al., 2006). Therefore, the apparent requirement for TRPV1 in inflammatory pain may be 

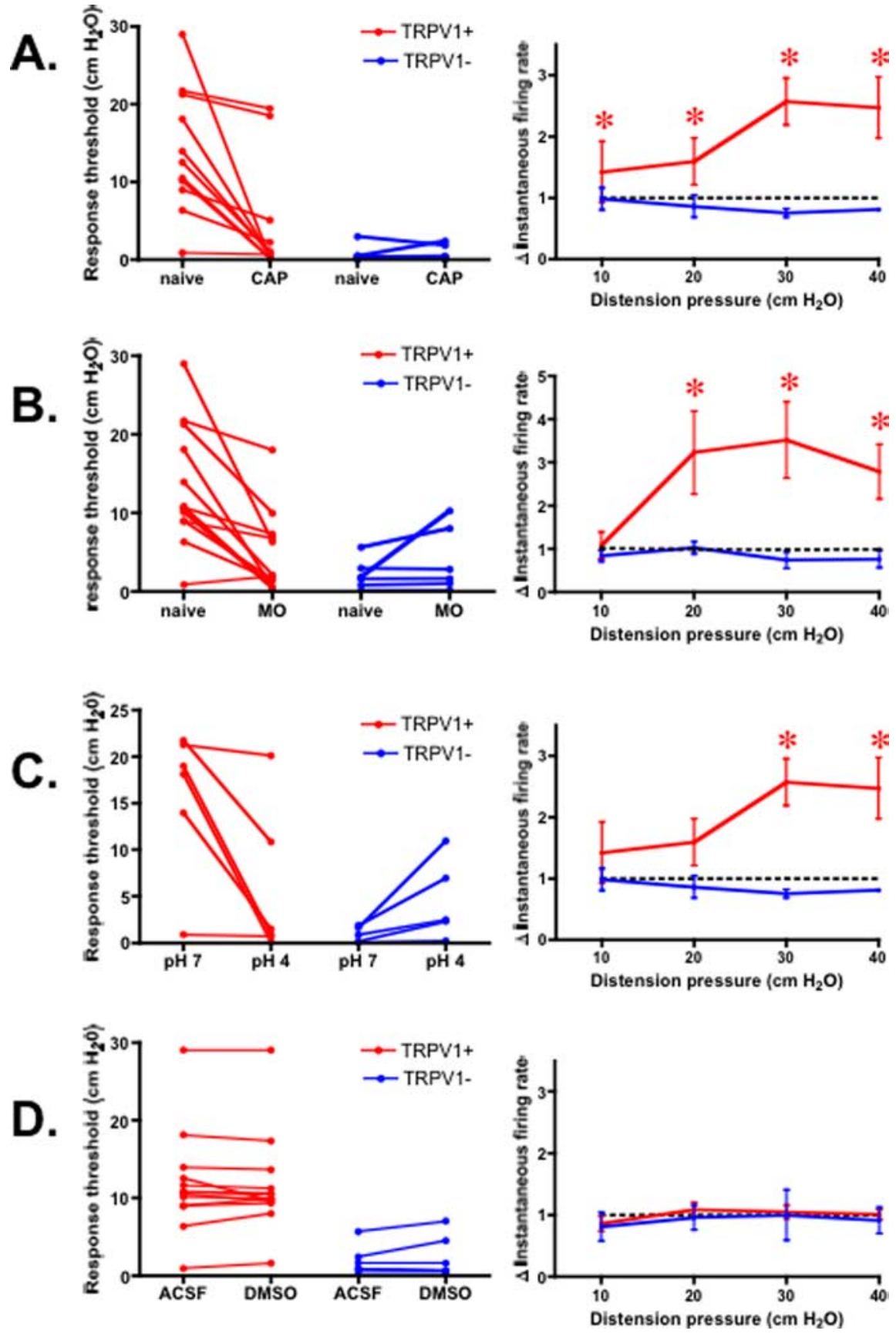

Figure 7. Capsaicin, mustard oil, and acid potentiate the response to distension. Responses to colon distension were obtained from sensory afferents before and after exposure to $\mathrm{CAP}(\boldsymbol{A}), \mathrm{MO}(\boldsymbol{B})$, vehicle (DMSO; $\boldsymbol{D})$, and/or pH $4(\boldsymbol{C})$. All cells were then stained for TRPV1. Response thresholds were calculated by regression analysis as previously. The dashed line in right panels indicates baseline. Capsaicin, mustard oil, and low pH reduced distension thresholds (left) and increased distension responses (right) in all TRPV1-positive cells. This was true for both LT and HT TRPV1-positive neurons. No effect of capsaicin, mustard oil, or low pH was seen on TRPV1-negative neurons ( $\left.{ }^{*} p<0.001\right)$. Importantly, exposure to vehicle (DMSO) did not affect distension response properties in colon afferents (bottom). Values are mean \pm SEM.

related to the function of the neurons that express this channel, as well as to the context of TRPV1 expression with other receptors and channels in the plasma membrane.

\section{References}

Akopian AN, Ruparel NB, Jeske NA, Hargreaves KM (2007) Transient receptor potential TRPA1 channel desensitization in sensory neurons is agonist dependent and regulated by TRPV1-directed internalization. J Physiol 583:175-193.

Akopian AN, Ruparel NB, Patwardhan A, Hargreaves KM (2008) Cannabi- noids desensitize capsaicin and mustard oil responses in sensory neurons via TRPA1 activation. J Neurosci 28:1064-1075.

Andersson DA, Gentry C, Moss S, Bevan S (2008) Transient receptor potential Al is a sensory receptor for multiple products of oxidative stress. J Neurosci 28:2485-2494.

Baloh RH, Tansey MG, Lampe PA, Fahrner TJ, Enomoto H, Simburger KS, Leitner ML, Araki T, Johnson EM Jr, Milbrandt J (1998) Artemin, a novel member of the GDNF ligand family, supports peripheral and central neurons and signals through the GFRalpha3-RET receptor complex. Neuron 21:1291-1302.

Bandell M, Story GM, Hwang SW, Viswanath V, Eid SR, Petrus MJ, Earley TJ, Patapoutian A (2004) Noxious cold ion channel TRPA1 is activated by pungent compounds and bradykinin. Neuron 41:849-857.

Bautista DM, Jordt SE, Nikai T, Tsuruda PR, Read AJ, Poblete J, Yamoah EN, Basbaum AI, Julius D (2006) TRPAl mediates the inflammatory actions of environmental irritants and proalgesic agents. Cell 124:1269-1282.

Bielefeldt K, Zhong F, Koerber HR, Davis BM (2006) Phenotypic characterization of gastric sensory neurons in mice. Am J Physiol Gastrointest Liver Physiol 291:G987-G997.

Birder LA (2006) Urinary bladder urothelium: molecular sensors of chemical/thermal/mechanical stimuli. Vascul Pharmacol 45:221-226.

Birder LA, Nakamura Y, Kiss S, Nealen ML, Barrick S, Kanai AJ, Wang E, Ruiz G, De Groat WC, Apodaca G, Watkins S, Caterina MJ (2002) Altered urinary bladder function in mice lacking the vanilloid receptor TRPV1. Nat Neurosci 5:856-860.

Brierley SM, Jones RC 3rd, Gebhart GF, Blackshaw LA (2004) Splanchnic and pelvic mechanosensory afferents signal different qualities of colonic stimuli in mice. Gastroenterology 127:166-178.

Brierley SM, Carter R, Jones W 3rd, Xu L, Robinson DR, Hicks GA, Gebhart GF, Blackshaw LA (2005) Differential chemosensory function and receptor expression of splanchnic and pelvic colonic afferents in mice. J Physiol 567:267-281.

Caterina MJ, Schumacher MA, Tominaga M, Rosen TA, Levine JD, Julius D (1997) The capsaicin receptor: a heat-activated ion channel in the pain pathway. Nature 389:816-824.

Caterina MJ, Leffler A, Malmberg AB, Martin WJ, Trafton J, Petersen-Zeitz KR, Koltzenburg M, Basbaum AI, Julius D (2000) Impaired nociception and pain sensation in mice lacking the capsaicin receptor. Science 288:306-313.

Christianson JA, Traub RJ, Davis BM (2006a) Differences in spinal distribution and neurochemical phenotype of colonic afferents in mouse and rat. J Comp Neurol 494:246-259.

Christianson JA, McIlwrath SL, Koerber HR, Davis BM (2006b) Transient receptor potential vanilloid 1-immunopositive neurons in the mouse are more prevalent within colon afferents compared to skin and muscle afferents. Neuroscience 140:247-257.

Christianson JA, Liang R, Ustinova EE, Davis BM, Fraser MO, Pezzone MA (2007) Convergence of bladder and colon sensory innervation occurs at the primary afferent level. Pain 128:235-243.

Cooke HJ, Xue J, Yu JG, Wunderlich J, Wang YZ, Guzman J, Javed N, Christofi FL (2004) Mechanical stimulation releases nucleotides that activate 
P2Y1 receptors to trigger neural reflex chloride secretion in guinea pig distal colon. J Comp Neurol 469:1-15.

Cruz-Orengo L, Dhaka A, Heuermann RJ, Young TJ, Montana MC, Cavanaugh EJ, Kim D, Story GM (2008) Cutaneous nociception evoked by 15-delta PGJ2 via activation of ion channel TRPA1. Mol Pain 4:30.

Dai Y, Wang S, Tominaga M, Yamamoto S, Fukuoka T, Higashi T, Kobayashi K, Obata K, Yamanaka H, Noguchi K (2007) Sensitization of TRPAl by PAR2 contributes to the sensation of inflammatory pain. J Clin Invest 117:1979-1987.

Daly D, Rong W, Chess-Williams R, Chapple C, Grundy D (2007) Bladder afferent sensitivity in wild-type and TRPV1 knockout mice. J Physiol 583:663-674.

Donnerer J, Schuligoi R, Stein C (1992) Increased content and transport of substance $\mathrm{P}$ and calcitonin gene-related peptide in sensory nerves innervating inflamed tissue: evidence for a regulatory function of nerve growth factor in vivo. Neuroscience 49:693-698.

Dyck PJ, Peroutka S, Rask C, Burton E, Baker MK, Lehman KA, Gillen DA, Hokanson JL, O’Brien PC (1997) Intradermal recombinant human nerve growth factor induces pressure allodynia and lowered heat-pain threshold in humans. Neurology 48:501-505.

Elitt CM, McIlwrath SL, Lawson JJ, Malin SA, Molliver DC, Cornuet PK, Koerber HR, Davis BM, Albers KM (2006) Artemin overexpression in skin enhances expression of TRPV1 and TRPA1 in cutaneous sensory neurons and leads to behavioral sensitivity to heat and cold. J Neurosci $26: 8578-8587$.

Fang X, McMullan S, Lawson SN, Djouhri L (2005) Electrophysiological differences between nociceptive and non-nociceptive dorsal root ganglion neurones in the rat in vivo. J Physiol 565:927-943.

Fang X, Djouhri L, McMullan S, Berry C, Waxman SG, Okuse K, Lawson SN (2006) Intense isolectin-B4 binding in rat dorsal root ganglion neurons distinguishes $\mathrm{C}$-fiber nociceptors with broad action potentials and high Nav1.9 expression. J Neurosci 26:7281-7292.

Fasanella KE, Christianson JA, Chanthaphavong RS, Davis BM (2008) Distribution and neurochemical identification of pancreatic afferents in the mouse. J Comp Neurol 509:42-52.

Gebhart GF (1999) Peripheral contributions to visceral hyperalgesia. Can J Gastroenterol 13 [Suppl A]:37A-41A.

Hille B (2001) Ion channels of excitable membranes, Ed 3. Sunderland, MA: Sinauer Associates.

Holzer P (2006) Efferent-like roles of afferent neurons in the gut: blood flow regulation and tissue protection. Auton Neurosci 125:70-75.

Hughes PA, Brierley SM, Young RL, Blackshaw LA (2007) Localization and comparative analysis of acid-sensing ion channel (ASIC1, 2, and 3) mRNA expression in mouse colonic sensory neurons within thoracolumbar dorsal root ganglia. J Comp Neurol 500:863-875.

Jones RC 3rd, Xu L, Gebhart GF (2005) The mechanosensitivity of mouse colon afferent fibers and their sensitization by inflammatory mediators require transient receptor potential vanilloid 1 and acid-sensing ion channel 3. J Neurosci 25:10981-10989.

Jones RC 3rd, Otsuka E, Wagstrom E, Jensen CS, Price MP, Gebhart GF (2007) Short-term sensitization of colon mechanoreceptors is associated with long-term hypersensitivity to colon distention in the mouse. Gastroenterology 133:184-194.

Jordt SE, Bautista DM, Chuang HH, McKemy DD, Zygmunt PM, Högestätt ED, Meng ID, Julius D (2004) Mustard oils and cannabinoids excite sensory nerve fibres through the TRP channel ANKTM1. Nature 427:260-265.

Koizumi S, Fujishita K, Inoue K, Shigemoto-Mogami Y, Tsuda M, Inoue K (2004) $\mathrm{Ca}^{2+}$ waves in keratinocytes are transmitted to sensory neurons: the involvement of extracellular ATP and P2Y2 receptor activation. Biochem J 380:329-338.

Kwan KY, Allchorne AJ, Vollrath MA, Christensen AP, Zhang DS, Woolf CJ, Corey DP (2006) TRPAl contributes to cold, mechanical, and chemical nociception but is not essential for hair-cell transduction. Neuron 50:277-289.

Lewin GR, Rueff A, Mendell LM (1994) Peripheral and central mechanisms of NGF-induced hyperalgesia. Eur J Neurosci 6:1903-1912.

Lynn PA, Blackshaw LA (1999) In vitro recordings of afferent fibres with receptive fields in the serosa, muscle and mucosa of rat colon. J Physiol 518:271-282.

Malin SA, Molliver DC, Koerber HR, Cornuet P, Frye R, Albers KM, Davis BM (2006) Glial cell line-derived neurotrophic factor family members sensitize nociceptors in vitro and produce thermal hyperalgesia in vivo. J Neurosci 26:8588-8599.

Malin SA, Davis BM, Koerber HR, Reynolds IJ, Albers KM, Molliver DC (2008) Thermal nociception and TRPV1 function are attenuated in mice lacking the nucleotide receptor P2Y(2). Pain 138:484-496.

Naliboff BD, Munakata J, Fullerton S, Gracely RH, Kodner A, Harraf F, Mayer EA (1997) Evidence for two distinct perceptual alterations in irritable bowel syndrome. Gut 41:505-512.

Ness TJ, Gebhart GF (1988) Colorectal distension as a noxious visceral stimulus: physiologic and pharmacologic characterization of pseudaffective reflexes in the rat. Brain Res 450:153-169.

Orozco OE, Walus L, Sah DW, Pepinsky RB, Sanicola M (2001) GFRalpha3 is expressed predominantly in nociceptive sensory neurons. Eur J Neurosci 13:2177-2182.

Ozaki N, Gebhart GF (2001) Characterization of mechanosensitive splanchnic nerve afferent fibers innervating the rat stomach. Am J Physiol Gastrointest Liver Physiol 281:G1449-G1459.

Ozaki N, Bielefeldt K, Sengupta JN, Gebhart GF (2002) Models of gastric hyperalgesia in the rat. Am J Physiol Gastrointest Liver Physiol 283:G666-G676.

Page AJ, Brierley SM, Martin CM, Price MP, Symonds E, Butler R, Wemmie JA, Blackshaw LA (2005) Different contributions of ASIC channels 1a, 2, and 3 in gastrointestinal mechanosensory function. Gut 54:1408-1415.

Robinson DR, McNaughton PA, Evans ML, Hicks GA (2004) Characterization of the primary spinal afferent innervation of the mouse colon using retrograde labelling. Neurogastroenterol Motil 16:113-124.

Rong W, Spyer KM, Burnstock G (2002) Activation and sensitisation of low and high threshold afferent fibres mediated by P2X receptors in the mouse urinary bladder. J Physiol 541:591-600.

Rong W, Hillsley K, Davis JB, Hicks G, Winchester WJ, Grundy D (2004) Jejunal afferent nerve sensitivity in wild-type and TRPV1 knockout mice. J Physiol 560:867-881.

Ruparel NB, Patwardhan AM, Akopian AN, Hargreaves KM (2008) Homologous and heterologous desensitization of capsaicin and mustard oil responses utilize different cellular pathways in nociceptors. Pain 135:271-279.

Sengupta JN, Gebhart GF (1994a) Characterization of mechanosensitive pelvic nerve afferent fibers innervating the colon of the rat. J Neurophysiol 71:2046-2060.

Sengupta JN, Gebhart GF (1994b) Mechanosensitive properties of pelvic nerve afferent fibers innervating the urinary bladder of the rat. J Neurophysiol 72:2420-2430.

Sugiura T, Bielefeldt K, Gebhart GF (2007) Mouse colon sensory neurons detect extracellular acidosis via TRPV1. Am J Physiol Cell Physiol 292:C1768-C1774.

Tominaga M, Caterina MJ, Malmberg AB, Rosen TA, Gilbert H, Skinner K, Raumann BE, Basbaum AI, Julius D (1998) The cloned capsaicin receptor integrates multiple pain-producing stimuli. Neuron 21:531-543.

Weskamp G, Otten U (1987) An enzyme-linked immunoassay for nerve growth factor (NGF): a tool for studying regulatory mechanisms involved in NGF production in brain and in peripheral tissues. J Neurochem 48:1779-1786.

Woolf CJ, Safieh-Garabedian B, Ma QP, Crilly P, Winter J (1994) Nerve growth factor contributes to the generation of inflammatory sensory hypersensitivity. Neuroscience 62:327-331. 